\title{
MAGNETIC HYSTERESIS AND CURIE TEMPERATURE IN NICKEL-CHROMIUM FERRITES SYNTHESIZED BY SOL-GEL PACS 75.75.+a, 75.60.-d AUTO-COMBUSTION METHOD
}

\section{Introduction}

As a result of fundamental researches, a new group of magnetic substances - nonmetallic magnetic materials, ferrites - was discovered [1]. More and more often, nanodispersed powders of ferrites become objects to study their magnetic properties, with the latter considerably depending on the size of particles and the morphology of clusters formed by them [2]. The most suitable method for producing the complicated oxide nanopowders is the sol-gel auto-combustion (SGAC) method, in which the aqueous solutions of metal salts are used [3]. A low temperature required to synthesize finely dispersed ferrite powders together with a high homogeneity of the latter comprises the main advantages of this method in comparison with the ceramic technology. At the same time, the microstructure of dispersed materials obtained in such a way, as well as

(c) V.S. BUSHKOVA, 2017

992 their magnetic properties, are not invariant and depend on many factors, the most important of them being the conditions, under which the materials are synthesized, and the temperature of their treatment.

Nanopowders of nickel ferrite, $\mathrm{NiFe}_{2} \mathrm{O}_{4}$, are successfully used in practice today. Usually, they are applied as fillers in magnetic fluids. Besides that, they can also be used in medicine for the magnetically controlled drug delivery [4], while developing electronic devices with new functionalities [5], and so forth. Depending on the scope of applications, the properties of nickel ferrite can be improved by properly substituting definite ions and selecting the treatment technology. Such magnetic parameters as the residual magnetization and the coercivity, which are the most important from the technological viewpoint, can be modified by substituting $\mathrm{Fe}^{3+}$ ions by $\mathrm{Cr}^{3+}$ ones [6]. The distributions of $\mathrm{Ni}^{2+}, \mathrm{Fe}^{3+}$, and $\mathrm{Cr}^{3+}$ cations over the spinel sublattices in nickel-chromium ferrites

ISSN 2071-0194. Ukr. J. Phys. 2017. Vol. 62, No. 11 
are known to critically depend on the method of ferrite synthesis. Moreover, those distributions change with the annealing temperature [7], which undoubtedly determines the magnetic and electric properties of specimens [8].

The substitution of $\mathrm{Fe}^{3+}$ ions by $\mathrm{Cr}^{3+}$ ones in nickel ferrite obtained with the use of the ceramic technology was studied in work [9] by applying the neutron diffraction method. Furthermore, in work [10], a series of $\mathrm{NiCr}_{x}(0 \leq x \leq 1.4)$ ferrites annealed at a temperature of $1473 \mathrm{~K}$ for $12 \mathrm{~h}$ was studied. It was found that, at the chrome content $x=1.4$, only an insignificant fraction of $\mathrm{Ni}^{2+}$ ions migrates from the octahedral sublattice B into the tetrahedral sublattice A. The authors of work [11], by applying the doublesintering method at temperatures 1273 and $1473 \mathrm{~K}$ for $12 \mathrm{~h}$, found that this migration of $\mathrm{Ni}^{2+}$ ions takes place already at $x=1.2$.

Concerning nickel-chromium ferrites in the nanosize state, the structural and magnetic properties of powders with the compositions $\mathrm{NiCr}_{x} \mathrm{Fe}_{2-x} \mathrm{O}_{4}$ $(x=0.1$ and 0.2$)$ were studied in work [12]. The powders were synthesized by mutually sedimentating the aqueous solutions of $\mathrm{NiCl}_{2} \cdot 6 \mathrm{H}_{2} \mathrm{O}, \mathrm{CrCl}_{3} \cdot 6 \mathrm{H}_{2} \mathrm{O}$, and $\mathrm{FeCl}_{3} \cdot 6 \mathrm{H}_{2} \mathrm{O}$ with the added $\mathrm{NaOH}$ solution. Afterward, the powders were additionally sintered at high temperatures in order to obtain a single spinel phase. The authors of work [13] also faced the singlephase problem, when obtaining $\mathrm{NiCr}_{x}(x=0,0.5$, and 1.0) ferrites, by using a variant of sol-gel methods, namely, the auto-combustion with the application of metal nitrates and urea $\left[\mathrm{CO}\left(\mathrm{NH}_{2}\right)_{2}\right]$ as a fuel mixture.

In work [14], the structural and magnetic properties of $\mathrm{NiCr}_{x} \mathrm{Fe}_{2-x} \mathrm{O}_{4}$ ferrites (with $x$ varying from 0 to 1 with an increment of 0.2 ) with the average size of crystallites from 20 to $30 \mathrm{~nm}$ were studied. The ferrites were synthesized by applying the wet-chemical sedimentation method and using sulfates of corresponding metal ions. The result of researches showed that some fraction of $\mathrm{Ni}^{2+}$ ions migrates from sublattice $\mathrm{B}$ to sublattice $\mathrm{A}$ at the chromium content $x=0.8$. According to the literature data [15], such a migration is possible already at an insignificant content of $\mathrm{Cr}^{3+}$ ions in the nickel ferrite composition, namely, at $x=0.2$.

The authors of work [16] fabricated powders of examined ferrites with an average crystallite size of 23-32 nm in the so-called "microwave" way, by us- ing the solutions of metal nitrates and a microwave oven. They studied the structural and magnetic properties of those ferrites by measuring the hysteresis loops at room temperature. At the same time, the cited work does not contain data concerning such magnetic parameters as the specific saturation magnetization $\sigma_{\mathrm{s}}$ and the coercivity $H_{\mathrm{c}}$.

Summarizing the aforesaid, it should be noted that, despite some knowledge about the crystalline and magnetic structures of bulk nickel-chromium ferrites, as well as their other physical properties, the morphology of small particles and the modifications of their magnetic microstructure and physical properties, which depend on the fabrication procedure and the temperature treatment regime, still remain poorly studied. They are not widely discussed in the scientific literature. In particular, in work [10], a low-temperature study of the magnetic properties of nickel-chromium ferrites was carried out at a temperature of $77 \mathrm{~K}$ and making use of Mössbauer spectroscopy. Nevertheless, the scientific literature does not contain information concerning the study of lowtemperature magnetic properties of $\mathrm{Ni}-\mathrm{Cr}$ ferrites, in particular, obtained with the use of the SGAC method, in which the required parameters were determined from the hysteresis-loop measurements in the low-frequency interval. The aim of this work is to perform the corresponding researches.

\section{Experimental Technique}

Ferrite powders of the $\mathrm{NiCr}_{x} \mathrm{Fe}_{2-x} \mathrm{O}_{4}$ system with $x=0,0.1,0.2,0.3,0.4$, and 0.5 were synthesized with the help of the SGAC method [17]. The phase composition of powders was monitored with the help of the $\mathrm{X}$-ray diffraction analysis on a diffractometer DRON3 , by using the $\mathrm{CuK}_{\alpha}$ radiation $(\lambda=0.154051 \mathrm{~nm})$. Registration was carried out in the angular interval $20^{\circ} \leq 2 \theta \leq 60^{\circ}$ with a step of $0.05^{\circ}$. The average size of powder crystallites, $\langle D\rangle=23 \div 43 \mathrm{~nm}$, was calculated with the help of the Scherrer equation and using the data concerning the broadening of diffraction maxima in the diffraction patterns of specimens.

Ferrimagnets can possess various forms. However, it is toroidal cores that are mainly used in pulse devices, because this shape allows the magnetic properties of materials to be used in full. Therefore, toroidal ferrite cores with an external diameter of $2.3 \times 10^{-2} \mathrm{~m}$, an internal diameter of $1.4 \times 10^{-2} \mathrm{~m}$, and a height of 


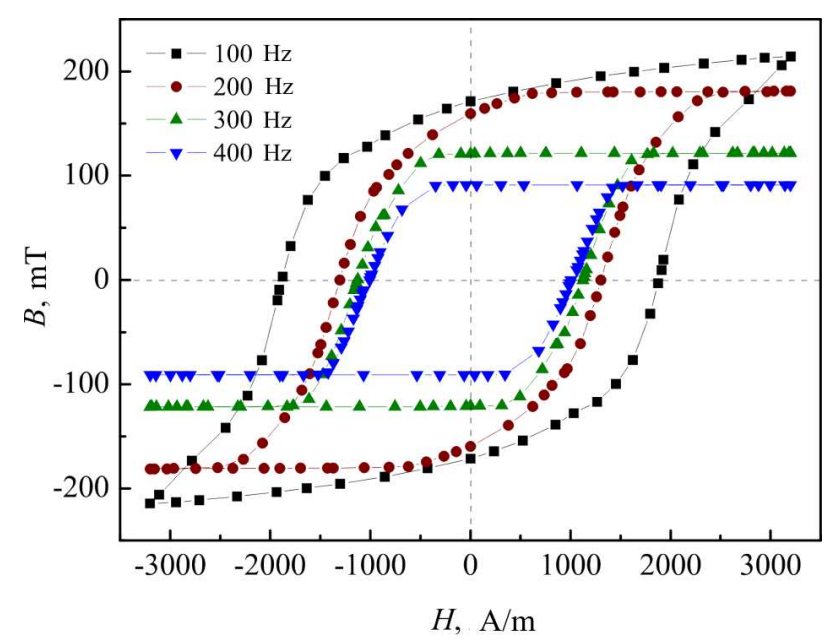

Fig. 1. Frequency magnetization reversal of $\mathrm{NiFe}_{2} \mathrm{O}_{4}$ ferrite

about $0.2 \times 10^{-2} \mathrm{~m}$ were fabricated by pressing the synthesized powders under a pressure of $3.3 \times 10^{8} \mathrm{~Pa}$. Then the specimens were sintered at a temperature of $1573 \mathrm{~K}$ for $5 \mathrm{~h}$ and slowly cooled down in air. As a result, single-phase specimens were obtained with a structure corresponding to the cubic spinel structure of the space group $F d 3 m$. The average size of ferrite crystallites in the annealed specimens amounted to 65-82 nm.

In order to determine the initial magnetic permeability $\mu$, induction coils were fabricated by winding a thin copper wire on the ferrite rings. The coil inductance $L$ was measured on a digital LCR meter of the E7-8 type, at a frequency of $1 \mathrm{kHz}$, in a weak magnetic field, and in a temperature interval of 293$873 \mathrm{~K}$.

It is very difficult to theoretically predict the main parameters of hysteresis loops at the stage of fabrication of a ferromagnetic material. Therefore, they are measured experimentally, as a rule. The magnetic properties of specimens were studied by plotting the

Table 1. Parameters of magnetic hysteresis loops for $\mathrm{NiFe}_{2} \mathrm{O}_{4}$ at $H=3200 \mathrm{~A} / \mathrm{m}$

\begin{tabular}{|c|c|c|c|c|}
\hline$f, \mathrm{~Hz}$ & $H_{\mathrm{c}}, \mathrm{A} / \mathrm{m}$ & $B_{\mathrm{r}}, \mathrm{mT}$ & $B_{\max }, \mathrm{mT}$ & $k_{\mathrm{s}}$ \\
\hline 100 & 1878 & 173 & 216 & 0.80 \\
200 & 1298 & 160 & 181 & 0.88 \\
300 & 1129 & 122 & 123 & 0.99 \\
400 & 982 & 91 & 91 & 1.00 \\
\hline
\end{tabular}

magnetic hysteresis loops registered on an electronic digital ferrometer F-5064 in a frequency interval of 100-400 Hz. The hysteresis loops were registered at the temperatures $T=77$ and $300 \mathrm{~K}$, and in an interval of magnetic field strength values, $H$, from 1600 to $12000 \mathrm{~A} / \mathrm{m}$ measured with an accuracy of $\pm 5 \mathrm{~A} / \mathrm{m}$.

\section{Results and Their Analysis}

Figure 1 illustrates the magnetization reversal of nickel ferrite in a frequency interval of $100-400 \mathrm{~Hz}$ at a magnetic field strength of $3200 \mathrm{~A} / \mathrm{m}$. As the frequency increases, the hysteresis loop becomes narrower, and the coercivity $H_{\mathrm{c}}$ and the residual magnetic induction $B_{\mathrm{r}}$ decrease. The ratio between the field induction and the field strength determined from this curve is called the dynamic magnetic permeability $\mu_{\mathrm{d}}$ :

$\mu_{\mathrm{d}}=\frac{1}{\mu_{0}} \frac{B_{\max }}{H_{\max }}$

where $\mu_{0}$ is the magnetic constant. As the field frequency increases, the dynamic permeability decreases owing to the inertia of magnetic processes. The area of a hysteresis loop obtained at a definite frequency and a definite magnetic field strength characterizes the losses $S_{\mathrm{d}}$ of electromagnetic energy, converted into heat, in a unit volume within one cycle of magnetization reversal. Those losses are created by eddy currents, magnetic viscosity, and hysteresis. In the case of weak fields, the quantity $S_{\mathrm{d}}$ can be expressed by the formula [18]

$S_{\mathrm{d}}=\pi B_{\max } H_{\mathrm{c}}$.

A specific feature of ferrites is their high specific resistance, which is approximately $10^{6}$ times higher than the corresponding parameter for electrotechnical steels. As a result, the losses for eddy currents become almost excluded for ferrites. Therefore, the influence of Foucault currents on the magnetic induction magnitude is insignificant. In this case, as the frequency increases, the magnetic induction in the core, for various reasons, cannot trace the magnetic field, and a reduction of magnetic parameters is observed. One of the origins resulting in the frequency dependence of the coercivity is a displacement of interfaces between the domains.

With the growth of the frequency, the area of a hysteresis loop decreases. Accordingly, the magnetic

ISSN 2071-0194. Ukr. J. Phys. 2017. Vol. 62, No. 11 
field losses for the specimen magnetization reversal also decrease. Note that the shape of a hysteresis loop approaches the rectangular one at that. Ferrites with a rectangular hysteresis loop are especially interesting from the viewpoint of their application in computer memory units. There are a number of specific requirements to the parameters of the materials and products of this type. The main of those parameters is the squareness of a hysteresis loop, $k_{\mathrm{S}}$ (see Table 1 ), which is defined as a ratio between the residual induction $B_{\mathrm{r}}$ and the maximum induction $B_{\max }$ :

$k_{\mathrm{s}}=\frac{B_{\mathrm{r}}}{B_{\max }}$.

One can see that the squareness of a hysteresis loop $k_{\mathrm{s}}$ equals 1 at a frequency of $400 \mathrm{~Hz}$, which allows nickel ferrite to be used in magnetic systems for the accumulation of information in electronic computers and as cores in magnetic switches and amplifiers.

A family of hysteresis loops for the $\mathrm{NiCr}_{0.3} \mathrm{Fe}_{1.7} \mathrm{O}_{4}$ specimen is shown in Fig. 2. Expectedly, with the growth of the magnetic field $H$, the residual magnetic induction $B_{\mathrm{r}}$ and the coercivity $H_{\mathrm{c}}$ increase.

Figure 3 exhibits the magnetic hysteresis loops for nickel-chromium ferrites registered at a frequency of $200 \mathrm{~Hz}$. One can see that, as the substitution degree $x$ in the $\mathrm{NiCr}_{x} \mathrm{Fe}_{2-x} \mathrm{O}_{4}$ system increases, the magnetic induction $B$ decreases, and the coercivity $H_{\mathrm{c}}$ grows. A reduction of the magnetic induction is associated with the tendency of $\mathrm{Cr}^{3+}$ ions to occupy octapositions [19], which gives rise to a weakening of the $A-B$ superexchange interaction. At the same time, the coercivity grows with the magnetocrystalline anisotropy [20]. Note that the coercivity depends not only on the anisotropy, but also on such factors as the microdeformation, magnetic morphology of particles, their size distribution, and the size of magnetic domains.

The magnitude of magnetic induction increases, as the temperature decreases from 300 to $77 \mathrm{~K}$, for all examined compositions of the ferrites concerned. The stabilization of the directions of the sublattice magnetic moments due to a reduction of thermal excitations, when the ferrite specimens are cooled down, is known to be the most probable reason giving rise to an increase of the magnetic induction in the case of massive ferrite specimens with crystallite sizes exceeding $100 \mu \mathrm{m}$. In the case of ferrites in the nanocrystalline state, an alternative origin of this

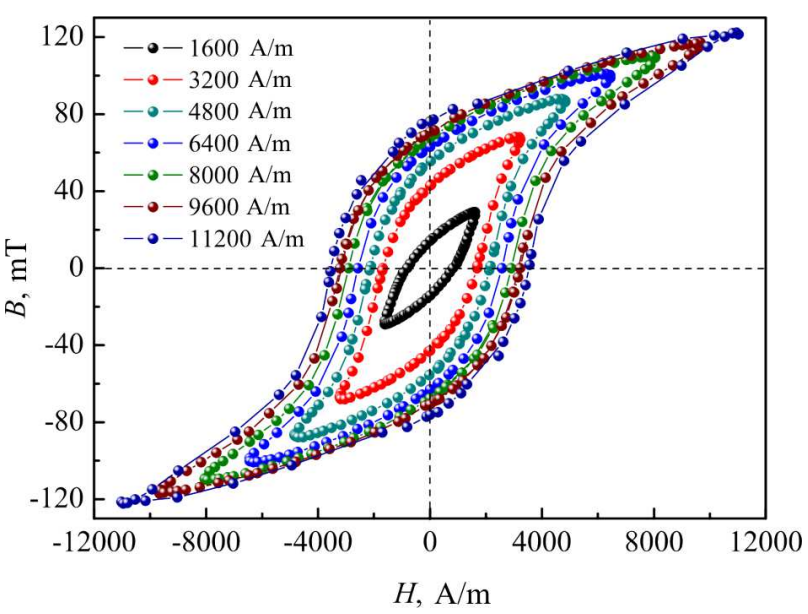

Fig. 2. Cyclic magnetization reversals of $\mathrm{NiCr}_{0.3} \mathrm{Fe}_{1.7} \mathrm{O}_{4}$ ferrite at $f=200 \mathrm{~Hz}$
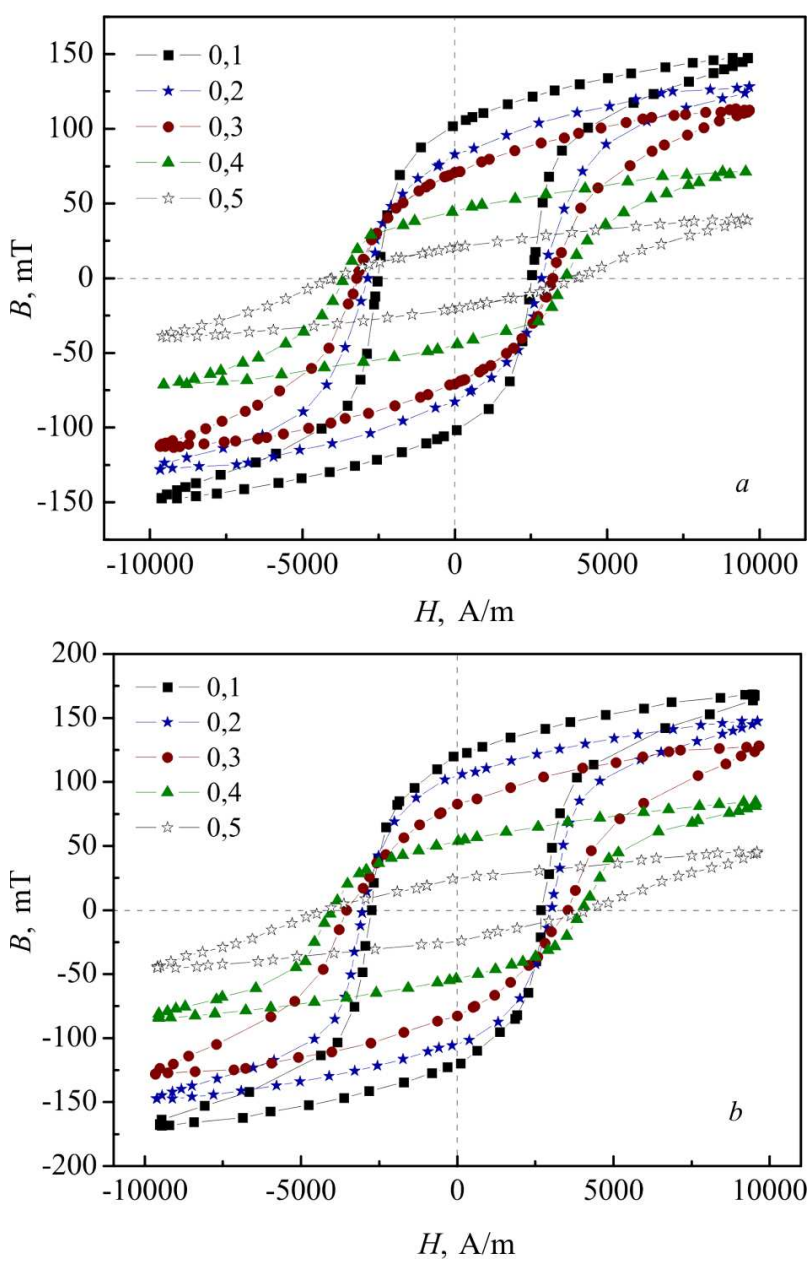

Fig. 3. Hysteresis loops for $\mathrm{NiCr}_{x} \mathrm{Fe}_{2-x} \mathrm{O}_{4}$ ferrites measured at temperatures of $300(a)$ and $77 \mathrm{~K}(b)$ 
Table 2. Parameters of magnetic hysteresis loops for $\mathbf{N i}-\mathbf{C r}$ ferrites

\begin{tabular}{|c|c|c|c|c|c|c|c|c|}
\hline \multirow{2}{*}{$\begin{array}{l}\text { Chromium } \\
\text { content } x\end{array}$} & \multicolumn{4}{|c|}{$T=300 \mathrm{~K}$} & \multicolumn{3}{|c|}{$T=77 \mathrm{~K}$} & \multirow{2}{*}{$\begin{array}{c}T=0 \mathrm{~K} \text { (extrapolation) } \\
\sigma_{\mathrm{s} 0}, \mathrm{~A} \cdot \mathrm{m}^{2} \cdot \mathrm{kg}^{-1}\end{array}$} \\
\hline & $H_{\mathrm{c}}, \mathrm{A} / \mathrm{m}$ & $\sigma_{\mathrm{s}}, \mathrm{A} \cdot \mathrm{m}^{2} \cdot \mathrm{kg}^{-1}$ & $\sigma_{\mathrm{s}}[24], \mathrm{A} \cdot \mathrm{m}^{2} \cdot \mathrm{kg}^{-1}$ & $t, \mathrm{~nm}$ & $H_{\mathrm{c}}, \mathrm{A} / \mathrm{m}$ & $\sigma_{\mathrm{s}}, \mathrm{A} \cdot \mathrm{m}^{2} \cdot \mathrm{kg}^{-1}$ & $t, \mathrm{~nm}$ & \\
\hline 0.0 & 2100 & 33.9 & - & 0.22 & 2484 & 34.3 & 0.04 & 34.45 \\
\hline 0.1 & 2525 & 31.0 & 28.2 & 1.51 & 2740 & 33.8 & 0.40 & 34.84 \\
\hline 0.2 & 2848 & 26.8 & 24.3 & 0.97 & 3064 & 28.4 & 0.28 & 29.00 \\
\hline 0.3 & 3179 & 22.9 & 10.1 & 1.60 & 3517 & 25.4 & 0.42 & 26.32 \\
\hline 0.4 & 3618 & 14.7 & - & 1.77 & 3989 & 16.5 & 0.44 & 17.17 \\
\hline 0.5 & 3971 & 7.7 & - & 2.01 & 4283 & 8.9 & 0.51 & 9.33 \\
\hline
\end{tabular}

Table 3. Distribution of cations

and magnetic parameters of $\mathrm{NiCr}_{x} \mathrm{Fe}_{2-x} \mathrm{O}_{4}$

\begin{tabular}{|c|c|c|c|c|c|}
\hline$x$ & $\begin{array}{c}\text { Distribution of cations } \\
\text { [17] }\end{array}$ & $\begin{array}{c}M, \\
\mathrm{~g} / \mathrm{mol}\end{array}$ & $\begin{array}{c}m_{\mathrm{th}}, \\
\mu_{\mathrm{B}}\end{array}$ & $\begin{array}{c}m_{\mathrm{exp}} \\
(300 \mathrm{~K}) \mu_{\mathrm{B}}\end{array}$ & $\begin{array}{c}m_{\mathrm{exp}} \\
(77 \mathrm{~K}) \mu_{\mathrm{B}}\end{array}$ \\
\hline 0.0 & $(\mathrm{Fe})[\mathrm{NiFe}] \mathrm{O}_{4}$ & 234.4 & 2.0 & 1.42 & 1.44 \\
\hline 0.1 & $(\mathrm{Fe})\left[\mathrm{NiCr}_{0.1} \mathrm{Fe}_{0.9}\right] \mathrm{O}_{4}$ & 234.0 & 1.8 & 1.30 & 1.41 \\
\hline 0.2 & $(\mathrm{Fe})\left[\mathrm{NiCr}_{0.2} \mathrm{Fe}_{0.8}\right] \mathrm{O}_{4}$ & 233.6 & 1.6 & 1.12 & 1.19 \\
\hline 0.3 & $(\mathrm{Fe})\left[\mathrm{NiCr}_{0.3} \mathrm{Fe}_{0.7}\right] \mathrm{O}_{4}$ & 233.2 & 1.4 & 0.96 & 1.06 \\
\hline 0.4 & $(\mathrm{Fe})\left[\mathrm{NiCr}_{0.4} \mathrm{Fe}_{0.6}\right] \mathrm{O}_{4}$ & 232.8 & 1.2 & 0.61 & 0.69 \\
\hline 0.5 & $(\mathrm{Fe})\left[\mathrm{NiCr}_{0.5} \mathrm{Fe}_{0.5}\right] \mathrm{O}_{4}$ & 232.5 & 1.0 & 0.32 & 0.37 \\
\hline
\end{tabular}

phenomenon can be the presence of such particles in the specimens, which are in the superparamagnetic state at a temperature of $300 \mathrm{~K}[21]$. As the concentration of $\mathrm{Cr}^{3+}$ ions increases, the number of such particles becomes larger. Concerning the coercivity, it also grows, as the temperature decreases.

The dependence of the magnetic characteristics of ferrites on their composition at a frequency of $200 \mathrm{~Hz}$ and in a magnetic field of $12000 \mathrm{~A} / \mathrm{m}$ is shown in Table 2. Note that, for ferrites of the $\mathrm{NiCr}_{x} \mathrm{Fe}_{2-x} \mathrm{O}_{4}$ system, which were obtained,by using the doublesintering ceramic method at temperatures of 1273 and $1473 \mathrm{~K}$ for $12 \mathrm{~h}$, the specific saturation magnetization $\sigma_{\mathrm{s}}$ decreases with the growth of $x$ and varies within an interval of $14-39 \mathrm{~A} \mathrm{~m}^{2} / \mathrm{kg}$ [10]. The specific saturation magnetization is proportional to the size of crystallites. For instance, $\sigma_{\mathrm{s}}=47.7 \mathrm{~A} \mathrm{~m}^{2} / \mathrm{kg}$ for the ferrite with the Cr content $x=0$ and an average crystallite size of $147 \mathrm{~nm}$, which was synthesized, by using the oxalate impregnation method [22]. The specific saturation magnetization $\sigma_{\mathrm{s}}$ determined for $\mathrm{NiFe}_{2} \mathrm{O}_{4}$ at room temperature agrees well with the results of work [23] $\left(\sigma_{\mathrm{s}}=34.5 \mathrm{~A} \mathrm{~m}^{2} / \mathrm{kg}\right)$. At the same time, the authors of work [24] obtained somewhat lower values for $\sigma_{\mathrm{s}}$ (see Table 2).

The content of cations in nano-sized $\mathrm{Ni}-\mathrm{Cr}$ ferrite powders can be described by the formula $\left(\mathrm{Fe}^{3+}\right)\left[\mathrm{Ni}^{2+} \mathrm{Fe}_{1-x}^{3+} \mathrm{Cr}_{x}^{3+}\right] \mathrm{O}_{4}^{2-}$ [17]. The magnetic moment $m_{\text {th }}$ per formula unit is determined as the algebraic sum of magnetic moments of the tetrahedral $(A)$ and octahedral $(B)$ sublattices:

$m_{\mathrm{th}}=m(B)-m(A)$.

From the distribution of cations between the spinel sublattices and the values of ionic magnetic moments in positions $\mathrm{A}$ and $\mathrm{B}$, we evaluated the magnetic moment per molecule. The substitutions of $\mathrm{Fe}^{3+}$ ions with the magnetic moment $5 \mu_{\mathrm{B}}$ by $\mathrm{Cr}^{3+}$ ones with the magnetic moment $3 \mu_{\mathrm{B}}$ results in a general reduction of the magnetic moment of the ferrite system. This tendency for magnetic moments of the specimens to decrease with the growth of the substitution degree $x$ takes place owing to the reduction of $m$ in sublattice $\mathrm{B}$ due to the dominating presence of $\mathrm{Cr}^{3+}$ ions.

Experimental spin magnetic moments in the Bohr magneton units were obtained using the formula [25]

$m_{\exp }=\frac{M \sigma_{\mathrm{s}}}{N_{\mathrm{A}} \mu_{\mathrm{B}}}$,

where $M$ is the molar mass, $N_{\mathrm{A}}$ the Avogadro constant, and $\mu_{\mathrm{B}}$ the Bohr magneton. From whence, we obtain

$m_{\exp }=\frac{M \sigma_{\mathrm{s}}}{5585}$.

The corresponding values are quoted in Table 3 . It should be noted that the pure nickel ferrite has the 
highest magnetic moment among the researched specimens. The above-presented results indicate that the magnitude of $m_{\exp }$ decreases with the growth of the chromium content in the specimens both at room temperature and at $77 \mathrm{~K}$.

According to the results of work [23], $m_{\exp }=$ $=1.44 \mu_{\mathrm{B}}$ for $\mathrm{NiFe}_{2} \mathrm{O}_{4}$ at room temperature, which is very close to $1.42 \mu_{\mathrm{B}}$. However, it should be noted that the values experimentally obtained for the magnetic moment, $m_{\text {exp }}$, are much lower than the theoretical ones, $m_{\mathrm{th}}$. A similar discrepancy between the magnetic moment values for the indicated chemical composition of ferrites was obtained in work [10]. On the one hand, it can be interpreted as the effect of tilted spins [26] within the same sublattice, A or B, in accordance with the Néel model extended by Yafet and Kittel [27]. Furthermore, since the pressed ferrite powders were subjected to the long-term sintering at a high temperature, a redistribution of cations between the spinel sublattices most likely took place.

On the other hand, it is well known that, unlike the case of massive ferrites with large crystallites, the magnetization of fine grains strongly depends of the thickness $t$ of the surface layer with a violated magnetic structure [28]. The specific saturation magnetization is related to the parameter $t$ by the expression

$\sigma_{\mathrm{s}}=\sigma_{\mathrm{s} 0}\left(1-\frac{2 t}{D}\right)^{3}$,

where $\sigma_{\mathrm{s}}$ and $\sigma_{\mathrm{s} 0}$ correspond to the specific magnetization of nano-sized grains at room temperature and $T=0 \mathrm{~K}$, respectively, $D$ is the average grain diameter, and $t$ the nonmagnetic shell thickness. From Eq. (7), we obtain [29]

$t=\frac{D}{2}\left(1-\left(\frac{\sigma_{\mathrm{s}}}{\sigma_{s 0}}\right)^{1 / 3}\right)$.

The values of the specific saturation magnetization $\sigma_{\mathrm{s} 0}$ were determined by extrapolating the function $\sigma_{\mathrm{s}}(T)$ to its intersection with the line $T=0$ (see Table 2).

An important characteristic of the magnetic properties of ferrites is their initial magnetic permeability $\mu_{i}$. Its temperature dependences are depicted in Fig. 4. One can see that, for each examined ferrite composition, the magnetic permeability reaches a specific maximum value at a specific temperature and then drastically decreases. It was known [30] that

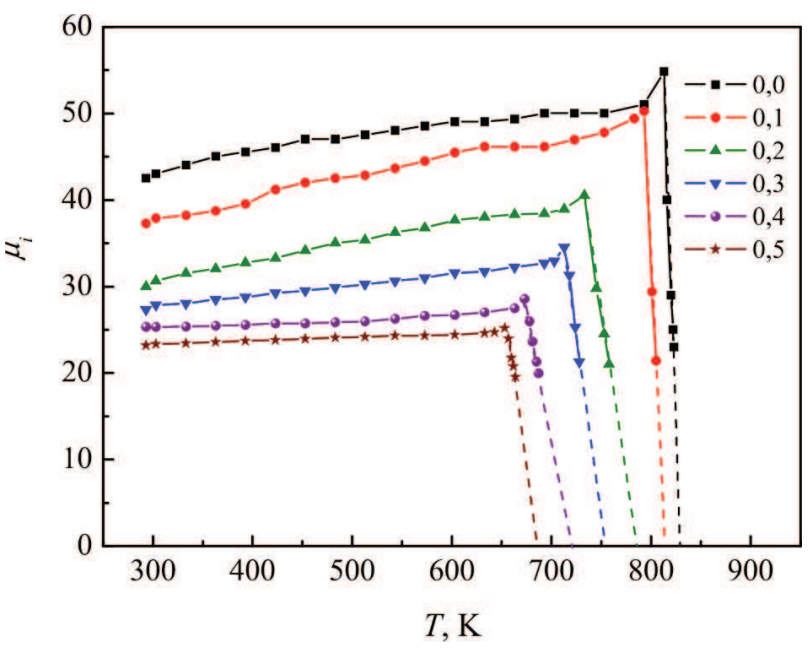

Fig. 4. Temperature dependences of the magnetic permeability of $\mathrm{NiCr}_{x} \mathrm{Fe}_{2-x} \mathrm{O}_{4}$ ferrites for various $x$

the maximum of the initial magnetic permeability is observed at a temperature slightly below the Curie point. Therefore, the true Curie temperature of ferrites was determined by linearly extrapolating the steepest section in the dependence $\mu(T)$ to the intersection with the abscissa axis.

Table 4 contains the values of the temperature $T_{\mathrm{c}}$, at which the substance loses its ferromagnetic properties and transits into the paramagnetic state. It should be noted that, as the substitution degree $x$ increases, both $\mu_{i}$ and $T_{\mathrm{c}}$ decrease. The monotonic decrease of the Curie temperature is a result of the weaker A-B superexchange interaction with the growth of $x$ in the $\mathrm{NiCr}_{x} \mathrm{Fe}_{2-x} \mathrm{O}_{4}$ system [31].

For coarse-crystalline $\mathrm{NiFe}_{2} \mathrm{O}_{4}$ ferrite obtained with the use of the ceramic technology, the Curie temperature is known to equal $853 \mathrm{~K}$. The authors of work [15] obtained a Curie temperature of $846 \mathrm{~K}$ for the nickel ferrite synthesized by thr sintering of $\mathrm{NiO}$,

Table 4. Dependences of $\boldsymbol{\mu}_{\boldsymbol{i}}$

and $T_{\mathrm{c}}$ on the substitution degree $x$

\begin{tabular}{|c|c|c|c|c|}
\hline$x$ & $\mu_{i}$ & $T_{\mathrm{C}}(\mathrm{SGAC}), \mathrm{K}$ & $T_{\mathrm{c}}[15], \mathrm{K}$ & $T_{\mathrm{c}}[33], \mathrm{K}$ \\
\hline 0.0 & 42.6 & 831 & 846 & 856 \\
0.1 & 37.3 & 814 & - & - \\
0.2 & 30.1 & 784 & 804 & 818 \\
0.3 & 27.3 & 753 & - & - \\
0.4 & 25.4 & 719 & 744 & 752 \\
0.5 & 23.3 & 685 & - & 692 \\
\hline
\end{tabular}


$\mathrm{Fe}_{2} \mathrm{O}_{3}$, and $\mathrm{Cr}_{2} \mathrm{O}_{3}$ oxides at a temperature of $1623 \mathrm{~K}$ for $12 \mathrm{~h}$. Furthermore, the authors of work [33] obtained $T_{\mathrm{c}}=856 \mathrm{~K}$ for a specimen with the same composition, which was synthesized at a temperature of $1473 \mathrm{~K}$ also for $12 \mathrm{~h}$, by using the precursors $\mathrm{NiCO}_{3}$, $\mathrm{Fe}_{2} \mathrm{O}_{3}$, and $\mathrm{Cr}_{2} \mathrm{O}_{3}$. At the same time, for the $\mathrm{NiFe}_{2} \mathrm{O}_{4}$ ferrite obtained within the SGAC method, the Curie temperature is lower by 15 and $25 \mathrm{~K}$, respectively (see Table 3). Moreover, the same tendency is observed for other specimens of the $\mathrm{NiCr}_{x} \mathrm{Fe}_{2-x} \mathrm{O}_{4}$ system.

The decrease of the Curie temperature in comparison with that in massive ferrites containing large crystallites can be associated with the reduction of particle sizes, which is explained in the framework of the theory of ferrimagnetic molecular field [34]. According to this theory, the magnetization decreases monotonically, as the temperature increases until it vanishes at $T=T_{\mathrm{c}}$. The smaller the size of magnetic particles, the lower is the saturation magnetization of ferrites and the lower is the Curie temperature. In particular, for $\mathrm{NiFe}_{2} \mathrm{O}_{4}$ particles obtained with the use of the chemical coprecipitation method, the Curie temperature amounts to $798 \mathrm{~K}$, if the the average particle size equals $32 \mathrm{~nm}$ [35], and to $820 \mathrm{~K}$ for 53-nm particles [36]. In work [31], it was revealed that the reduction of the $T_{\mathrm{c}}$ value for finely dispersed particles with respect to that for coarse-crystalline nickel-cobalt ferrites is substantially affected by the thickness of the near-surface layer of crystallites with a violated magnetic structure.

\section{Conclusions}

Among plenty of synthesis methods, the SGAC technology makes it possible to fabricate nano-sized powders with interesting magnetic properties. For example, it was found that, as the magnetic field frequency increases, the residual magnetic induction and the coercivity decrease. The squareness of a hysteresis loop, $k_{\mathrm{s}}$, grows at that, being equal to 1 for $\mathrm{NiFe}_{2} \mathrm{O}_{4}$ ferrite at $H=3200 \mathrm{~A} / \mathrm{m}$ and a frequency of $400 \mathrm{~Hz}$.

It is found that if the chromium content in the studied specimens grows, the specific saturation magnetization $\sigma_{\mathrm{s}}$ decreases from 33.9 to $7.7 \mathrm{~A} \mathrm{~m}^{2} / \mathrm{kg}$ at room temperature, whereas the coercivity increases from 2100 to $3971 \mathrm{~A} / \mathrm{m}$. Note that the magnetic characteristics become better for all ferrites of the $\mathrm{NiCr}_{x} \mathrm{Fe}_{2-x} \mathrm{O}_{4}$ system, as the temperature decreases from 300 to $77 \mathrm{~K}$.

\section{8}

The experimentally measured values of the magnetic moment $m$ are somewhat lower in comparison with the theoretical values. This discrepancy can be explained in the framework of the Yafet-Kittel model as a manifestation of the effect of tilted spins, as well as by a considerable influence of the thickness of a near-surface layer with a violated magnetic structure on the magnetic properties of ferrites. At room temperature, this thickness equals $0.22-2.01 \mathrm{~nm}$. In addition, the thickness of the near-surface layer considerably affects the decrease of the Curie temperature in fine-grained $\mathrm{Ni}-\mathrm{Cr}$ ferrites in comparison with their coarse-crystalline counterparts.

1. Ye.O. Chemes, Yu.S. Yampolskyi. Electrotechnical Devices of Radio-Electronic Facilities (Bakhva, 2014) (in Ukrainian).

2. V.O. Leontiev, S.V. Bevz, V.A. Vidmish. Electrotechnical Materials (VNTU, 2013) (in Ukrainian).

3. B.K. Ostafijchuk, V.S. Bushkova, V.V. Moklyak, R.V. Ilnitsky. Synthesis and magnetic microstructure of nanoparticles of zinc-substituted magnesium ferrites. Ukr. Fiz. Zh. 60, 1236 (2015) (in Ukrainian).

4. C.H. Cunningham, T. Arai, P.C. Yang, M.V. Connell, J.M. Pauly, S.M. Connolly. Positive contrast magnetic resonance imaging of cells labeled with magnetic nanoparticles. Magn. Reson. Med. 53, 999 (2005).

5. N.E. Kazantseva, Y.I. Bespyatykh, I. Sapurina, J. Stejskal, J. Vilcakova, P. Sáha. Magnetic materials based on manganese-zinc ferrite with surface-organized polyaniline coating. J. Magn. Magn. Mater. 301, 155 (2006).

6. M. Patange, S.E. Shirsath, S.S. Jadhav, K.S. Lohar, D.R. Mane, K.M. Jadhav. Rietveld refinement and switching properties of $\mathrm{Cr}^{3+}$ substituted $\mathrm{NiFe}_{2} \mathrm{O}_{4}$ ferrites. Mater. Lett. 64, 722 (2010).

7. S. Mitra, M. Bidyananda, A. Kumar Samanta. Cation distribution in Cr-spinels from the Sittampundi layered complex and their intra-crystalline thermodynamics. Current Sci. 90, 435 (2006).

8. I.S. Ahmed Farag, M.A. Ahmed, S.M. Hammad, A.M. Moustafa. Study of cation distribution in $\mathrm{Cu}_{0.7}\left(\mathrm{Zn}_{0.3-x} \mathrm{Mg}_{x}\right) \mathrm{Fe}_{1.7} \mathrm{Al}_{0.3} \mathrm{O}_{4}$ by X-ray diffraction using Rietveld method. Egypt. J. Sol. 24, 215 (2001).

9. A.K. Ghatage, S.A. Patil, S.K. Paranjpe. Neutron diffraction study of chromium substituted nickel ferrite. Solid State Commun. 98, 885 (1996).

10. A. Rais, A.M. Gismelseed, I.A. Al-Omari. Cation distribution and magnetic properties of nickel-chromium ferrites $\mathrm{NiCr}_{x} \mathrm{Fe}_{2-x} \mathrm{O}_{4}(0 \leq x \leq 1.4)$. Phys. Status Solidi $B \mathbf{2 4 2}$, 1497 (2005).

11. A.M. Gismelseed, A.A. Yousif. Mössbauer study of chromium-substituted nickel ferrites. Physica $B$ 370, 215 (2005).

ISSN 2071-0194. Ukr. J. Phys. 2017. Vol. 62, No. 11 
12. E.H. El-Ghazzawy, S.N. Alamri. $\mathrm{NiCr}_{x} \mathrm{Fe}_{2-x} \mathrm{O}_{4}$ ferrite nanoparticles and their composites with polypyrrole: Synthesis, characterization and magnetic properties. Bull. Mater. Sci. 38, 915 (2015).

13. A.C.F.M. Costa, D.A. Vieira, P. Sarubo-Junior, D.R. Cornejo, R.H.G.A. Kiminami. Avaliação de diferentes rotas de síntese para preparação de nanopós de ferritas de níquel dopadas com cromo. Rev. Electron. Mater. Process. 3, 40 (2008).

14. S.M. Patange, S.E. Shirsath, S.S. Jadhav, K.M. Jadhav. Cation distribution study of nanocrystalline $\mathrm{NiFe}_{2-x} \mathrm{Cr}_{x} \mathrm{O}_{4}$ ferrite by XRD, magnetization and Mössbauer spectroscopy. Phys. Status Solidi A 209, 347 (2012).

15. S.H. Lee, S.J. Yoon, G.J. Lee, H.S. Kim, Ch.H. Yo, K. Ahn, D.H. Lee, K.H. Kim. Electrical and magnetic properties of $\mathrm{NiCr}_{x} \mathrm{Fe}_{2-x} \mathrm{O}_{4}$ spinel $(0 \leq x \leq 0.6)$. Mater. Chem. Phys. 61, 147 (1999).

16. A. Baykal, A.Z. Elmal, M. Sertkol, H. Sozeri. Structural and magnetic properties of $\mathrm{NiCr}_{x} \mathrm{Fe}_{2-x} \mathrm{O}_{4}$ nanoparticles synthesized via microwave method. J. Supercond. Nov. Magn. 28, 3405 (2015).

17. V.S. Bushkova, I.P. Yaremiy, R.P. Lisovskiy, B.V. Karpyk. Structure and sorption characteristics of $\mathrm{NiCr}_{x} \mathrm{Fe}_{2-x} \mathrm{O}_{4}$ ferrite powders. J. Nano-Electron. Phys. 9, 02011 (2017).

18. S. Krupička. Physik der Ferrite und der Verwandten Magnetischen Oxide (Vieweg und Teubner, 1973).

19. K. Maaz, W. Khalid, A. Mumtaz, S.K. Hasanain, J. Liu, J.L. Duan. Magnetic characterization of $\mathrm{Co}_{1-x} \mathrm{Ni}_{x} \mathrm{Fe}_{2} \mathrm{O}_{4}$ $(0 \leq x \leq 1)$ nanoparticles prepared by co-precipitation route. Physica E 41, 593 (2009).

20. S.T. Alone, S.E. Shirsath, R.H. Kadam, K.M. Jadhav. Chemical synthesis, structural and magnetic properties of nano-structured $\mathrm{Co}-\mathrm{Zn}-\mathrm{Fe}-\mathrm{Cr}$ ferrite. J. Alloy. Compd. 509, 5055 (2011).

21. A.A. Eliseev, A.V. Lukashin. Physical Properties of Substances in Nanocrystalline State (Moscow State Univ., 2007) (in Russian).

22. M.A. Gabal, Y.M. Al Angari. Effect of chromium ion substitution on the electromagnetic properties of nickel ferrite. Mater. Chem. Phys. 118, 153 (2009).

23. M.A. Gabal, S. Kosa, T.S. El Muttairi. Magnetic dilution effect of nano-crystalline $\mathrm{NiFe}_{2} \mathrm{O}_{4}$ synthesized via sucroseassisted combustion route. Ceram. Intern. 40, 675 (2014).

24. D.B. Pawar, S.M. Rathod. Synthesis of nano sized chromium $\left(\mathrm{Cr}^{3+}\right)$ substituted nickel ferrite and their magnetic properties by sol-gel pethnique. Bionano Front. 8, 123 (2015).

25. M.A. Hakim, S.K. Nath, S.S. Sikder, K.H. Maria. Cation distribution and electromagnetic properties of spinel type Ni-Cd ferrites. J. Phys. Chem. Solids 74, 1316 (2013).

26. S.M. Patange, S.E. Shirsath, B.G. Toksha, S.S. Jadhav, K.M. Jadhav. Electrical and magnetic properties of $\mathrm{Cr}^{3+}$ substituted nanocrystalline nickel ferrite. J. Appl. Phys. 106, 023914 (2009).

27. Y. Yafet, C. Kittel. Antiferromagnetic arrangements in ferrites. Phys. Rev. 87, 290 (1952).

28. M.K. Rangolia, M.C. Chhandbar, A.R. Tanna, K.B. Modi, G.J. Baldha, H.H. Joshi. Magnetic behaviour of nanosized and coarse powders of $\mathrm{Cd}-\mathrm{Ni}$ ferrites synthesized by wet-chemical route. Indian J. Pure Appl. Phys. 46, 60 (2008).

29. P.P. Gorbyk, I.V. Dubrovin, M.V. Abramov. Synthesis, structure, and magnetic properties of single-domain nanoparticles of solid solutions $\left(\mathrm{Fe}_{1-x} \mathrm{Mn}_{x}\right) \mathrm{Fe}_{2} \mathrm{O}_{4} \cdot \mathrm{Po}-$ verkhnost 7, 186 (2015) (in Ukrainian).

30. F. Nesa, A.K.M. Zakaria, M.A. Saeed Khan, S.M. Yunus, A.K. Das, S.G. Eriksson, M.N.I. Khan, D.K. Saha, M.A. Hakim. Structural and magnetic properties of $\mathrm{Cr}^{3+}$ doped Mg ferrites. World J. Condens. Matter Phys. 2, 27 (2012).

31. V.S. Bushkova. Effect of temperature on the structural and magnetic properties of $\mathrm{Ni}_{x} \mathrm{Co}_{1--x} \mathrm{Fe}_{2} \mathrm{O}_{4}$ Nanoparticles. J. Nano-Electron. Phys. 8, 01002 (2016).

32. Yu. Sitidze, H. Sato. Ferrites (Mir, 1960) (in Russian).

33. A. Rais, A. Addou, M. Ameri, N. Bouhadouza, A. Merine. On the magnetic compensation of magnesium doped $\mathrm{Ni}-\mathrm{Cr}$ ferrites. Appl. Phys. A 111, 665 (2013).

34. G. Nabiyouni, M.J. Fesharaki, M. Mozafari, J. Amighian. Characterization and magnetic properties of nickel ferrite nanoparticles prepared by ball milling technique. Chin. Phys. Lett. 27, 126401 (2010).

35. A.K. Nikumbh, A.V. Nagawade, G.S. Gugale, M.G. Chaskar, P.P. Bakare. The formation, structural, electrical, magnetic and Mossbauer properties of ferrispinels, $\mathrm{Cd}_{1-x} \mathrm{Ni}_{x} \mathrm{Fe}_{2} \mathrm{O}_{4}$. J. Mater. Sci. 37, 637 (2002).

36. S.P. Jadhav, B.G. Toksha, K.M. Jadhav, N.D. Shinde. Effect of cadmium substitution on structural and magnetic properties of nano sized nickel ferrite. Chin. J. Chem. Phys. 23, 459 (2010).

Received 22.06.17.

Translated from Ukrainian by O.I. Voitenko

\section{B.С. Бушкова}

\section{МАГНІТНИЙ ГІСТЕРЕЗИС}

I ТЕМПЕРАТУРА КЮРІ НІКЕЛЬ-ХРОМОВИХ

ФЕРИТІВ, ОТРИМАНИХ МЕТОДОМ

ЗОЛЬ-ГЕЛЬ ЗА УЧАСТІ АВТОГОРІННЯ

P е $з$ ю м е

Нанорозмірні нікель-хромові порошки феритів із загальною формулою $\mathrm{NiCr}_{x} \mathrm{Fe}_{2-x} \mathrm{O}_{4}$ синтезовано методом золь-гель за участі автогоріння (ЗГА). Всі склади феритів мають кубічну структуру шпінелі. Середній розмір порошків знаходився в межах 23-43 нм. Після пресування порошків та 
їх спікання за температури $1573 \mathrm{~K}$ середній розмір кристалітів становить 65-83 нм. Форма петель магнітного гістерезису підтверджує, що досліджувані зразки є магнітом'якими матеріалами завдяки низькій коерцитивній силі $H_{\mathrm{c}}$. Залишкова індукція $B_{\mathrm{r}}$ магнітного поля з ростом концентрації йонів $\mathrm{Cr}^{3+}$ зменшується за рахунок послаблення взаємодії між підгратками шпінелі в той час, як $H_{\mathrm{c}}$ зростає. Зі збільшенням у феритових зразках йонів $\mathrm{Cr}^{3+}$ зменшується значення питомої намагніченості насичення $\sigma_{\mathrm{s}}$ від $33,9 \mathrm{~A} \cdot \mathrm{M}^{2} \cdot \mathrm{k \Gamma}^{-1}$ до $7,7 \mathrm{~A} \cdot \mathrm{M}^{2} \cdot \mathrm{k} \Gamma^{-1}$, що свідчить про те, що менш магнітні йони хрому заміщають йони $\mathrm{Fe}^{3+}$ в октапі- дгратці феритів. Магнітні моменти, розраховані з використанням двопідг раткової моделі Нееля за розподілом катіонів, є дещо нижчі за значення, отримані експериментальним шляхом. Це зумовлено проявом ефекту скошених спінів та впливом товщини поверхневого шару $\mathrm{t}$ з порушеннями магнітної структури, який знаходиться в межах 0,22 2,01 нм. Зі зниженням температури вимірювань до $77 \mathrm{~K}$ магнітні параметри феритових осердь зростають, що зумовлено їх суперпарамагнітними властивостями. Температура Кюрі $T_{\mathrm{c}}$ спадає від $831 \mathrm{~K}$ до $685 \mathrm{~K}$ з ростом ступеня заміщення $x$. 